\title{
Does Stocking Rate Manipulation Promote Pasture Sustainability in the Humid Tropics?
}

\author{
William Bruce Campbell, ${ }^{1}$ Jesús Jarillo-Rodríguez, ${ }^{2}$ Silvia López-Ortiz, ${ }^{3}$ and \\ Epigmenio Castillo-Gallegos ${ }^{2}$
}

\begin{abstract}
Authors are ${ }^{1}$ Research Scientist and ${ }^{3}$ Professor, Colegio de Postgraduados, Campus Veracruz, Predio Tepetates, Municipio de Manlio Fabio Altamirano, Veracruz, Mexico, C.P. 91690; and ${ }^{2}$ Professor, Centro de Enseñanza, Investigación y Extensión en Ganaderia Tropical (CEIEGT), FMVZ-UNAM, Tlapacoyan, Veracruz, Mexico, C.P. 93600.
\end{abstract}

\begin{abstract}
Stocking rate manipulation was examined as a means of improving plant diversity (as a measure of pasture sustainability and forage value) in a native grass pasture used for dairy production in the humid tropics of Veracruz, Mexico. Given that environmental impact reduces biotic diversity, plant phylogenetic and functional diversity should decline with increased stocking rate. Stocking rates of 2,3 , and 4 cows $\cdot \mathrm{ha}^{-1}$ and a rotational grazing plan of $3 \mathrm{~d}$ of occupation and $27 \mathrm{~d}$ of rest per pasture were applied continuously over 5 yr. Across 200 quadrats in each of two replicate paddocks per treatment, observed species richness, phylogenetic diversity (average taxonomic distinctness based on species presence/absence), and functional diversity (life-cycle duration and growth habit) were assessed. Most species were forb/herbs and forb/herb-subshrubs. Perennial species declined with increased stocking rate $(F=16.36,0.05>P>0.02)$ while annual-perennial species increased $(F=76.88$, $0.01>P>0.005)$; the proportion of annual species was least prominent and did not differ significantly. Observed species richness and phylogenetic diversity did not differ significantly with stocking rate. The correlation between functional diversity for life-cycle duration and phylogenetic diversity was significant and positive, suggesting that plant communities were predominantly assembled randomly from the surrounding species pool rather than through interspecies interactions acting to naturally filter immigrant species, thus leading to more opportunistic and undesired species. Although grazing pressure was not sufficient to alter indices or production measures, they did reveal shifts that may precede further pasture decline, indicating pasture sustainability was not being achieved. These rapid assessment methods permit monitoring for early warnings of reductions in pasture sustainability and forage quality for cattle.
\end{abstract}

Key Words: grazing, growth habit, life-cycle duration, observed species richness, plant diversity, rapid survey assessment

\section{INTRODUCTION}

Rising demands for agricultural productivity will raise pressures on pastures in many regions of the world, increasing the difficulty for improving pasture sustainability. The general objective of land managers or ranchers in such systems is to increase forage yield so that higher stocking rates can be applied to improve animal production. Such goals, however, must be balanced by practices that avoid loss of biodiversity, freshwaters contaminated by agricultural runoff, degraded land, and invasions by undesired or introduced species (e.g., Harper et al. 1990; Archer 1995, 1996; Edwards et al. 2000; Smith et al. 2000; Campbell et al. 2010; see also Shachak et al. 2008), changes that lead to declines in production goals and financial returns (e.g., Friedel 1991; Laycock 1991; Holechek

\footnotetext{
Research funding was provided to J.J.R. by the Programa de Apoyo a Proyectos de Investigación e Innovación Tecnológica (PAPIIT) of the Universidad Nacional Autónoma de México, through grant IN205805, "Efecto de la carga animal bovina sobre la morfogénesis de gramas nativas y su calidad nutritiva en el trópico húmedo mexicano."

Correspondence: Dr. W. Bruce Campbell, c/o Dr. Francisco Osorio Acosta, Colegio de Postgraduados, Campus Veracruz, Predio Tepetates, Municipio de Manlio Fabio Altamirano, Km 88.5 Carretera Federal Xalapa-Veracruz, vía Paso de Ovejas entre los poblados de Puente Jula y Paso San Juan, Veracruz, Mexico, C.P. 91690 (alternatively Colegio de Postgraduados, Campus Veracruz, Apartado Postal 421, Veracruz, Veracruz, Mexico, C.P. 91700). Email: bruce_campbell3@hotmail.com
}

Manuscript received 1 July 2011; manuscript accepted 29 January 2013

(c) 2013 The Society for Range Management
1996). This is a difficult balance to achieve (Briske and Heitschmidt 1991; Stafford Smith 1996; Kauffman and Pyke 2001), especially in developing and underdeveloped regions of the world where poverty and near-subsistence rural living conditions are common. Such situations promote increased land use to meet subsistence needs and to supplement those needs with some market income from sales of dairy products and meat.

In the humid tropics of Mexico, more than $60 \%$ of livestock pastures are largely composed of native grasses in the genera Paspalum, Axonopus, Cynodon, and Setaria (Enríquez 1996; Améndola et al. 2005; Castillo et al. 2005). Such native grass pastures are the main source of forage for meat and dairy cattle in the state of Veracruz (Aluja and McDowell 1984; Menocal et al. 1992) and are important because they rapidly produce forage biomass and are adapted to tropical environments (Améndola et al. 2005). Yet animal production systems in the tropics are characterized by forage that is available only for short growing periods (Argel 2006), and native grass species in Veracruz generally have lower forage quality than introduced grasses (Enríquez 1996) because native grasses are more adapted to an adverse tropical environment (prolonged dry conditions and low soil fertility), resulting in low production, rapid maturity, and a subsequently rapid loss of nutritional quality (a rapid increase in fiber content and reduction in crude protein and leaf:stem ratio with rapid maturity) (Dabo et al. 1987). As such, more species-rich native grass pastures are often converted to less rich exotic grass pastures for intensive 
grazing by livestock (Asner et al. 2004). Alternatively, since older native grass forage has lower nutritional quality (Dabo et al. 1987), stocking rates are manipulated to prolong the time for active grass growth (i.e., increasing forage value) to improve animal performance (Aluja and McDowell 1984; Dabo et al. 1988; Ungar and Noy-Meir 1988; Enríquez 1996; Ackerman et al. 2001; Fike et al. 2003; Améndola et al. 2005; see also McNaughton 1979). Yet increased stocking rates or prolonged grazing periods negatively affect dry matter yield by reducing plant regrowth, altering pasture botanical composition, and influencing plant utilization and the expression of grazing resistance/tolerance among plant species (Briske 1996). At high enough levels, pasture structural modifications occur that alter livestock foraging behavior (e.g., Gibb 2006), resulting in decreased forage intake and animal performance- a contradiction to pasture and livestock sustainability objectives.

Just as important as extended forage productivity is the maintenance of plant diversity to help offset the shorter growing period for grasses. Retaining diverse plant species having different growth habits and phenologies provides a healthy forage mix for livestock and for the maintenance of ecosystem equilibrium and function (Johnson et al. 1996; Fonseca and Ganade 2001; Lyons et al. 2005; Provenza et al. 2007, 2009; Shachak et al. 2008; see also Villa-Herrera et al. 2009; Manríquez 2010).

The relation between the loss of community diversity (plant or animal) and the degree of disturbance imparted by environmental impact is not linear (Fig. 1), and different indicators of impact generally perform better in different regions along the conceptual curve. At low levels of disturbance, communities are generally resilient/tolerant, displaying few early signs of change and without significantly altering community composition (Fig. 1, region A), suggesting measures of functional traits may provide better insight under such conditions. As the degree of disturbance increases beyond thresholds of resilience/tolerance (Fig. 1, region B), its effects are more rapidly propagated throughout a community, resulting in more detectable changes in community structure and composition with smaller degrees of added impact. In this region, biomonitoring indices and measures of production are generally most effective. At higher levels of disturbance (Fig. 1, region $\mathrm{C}$ ), communities are profoundly disrupted as is physical habitat, and effects are often better assessed by focusing on the physical environment rather than biomonitoring indices or production measures. However, points defining the boundaries of each curve region and, thus, when a chosen measure is no longer informative are not exact; imagining such diagrams as having regions that blend, or grade, one into another is helpful in this regard. Using a range of indices and measures is, therefore, a practical approach when assessing disturbance.

To assess change in the phylogenetic diversity of plant communities resulting from impacts such as grazing, quantitative measurements are required for comparison (Magurran 2004), with species being the most natural and commonly accepted unit for such analyses. Phylogenetic variation is implicit in the perception of diversity, a property not encompassed by species richness alone (which treats all species equally). The greater the taxonomic difference among species, the greater the phylogenetic diversity (Clarke and Warwick

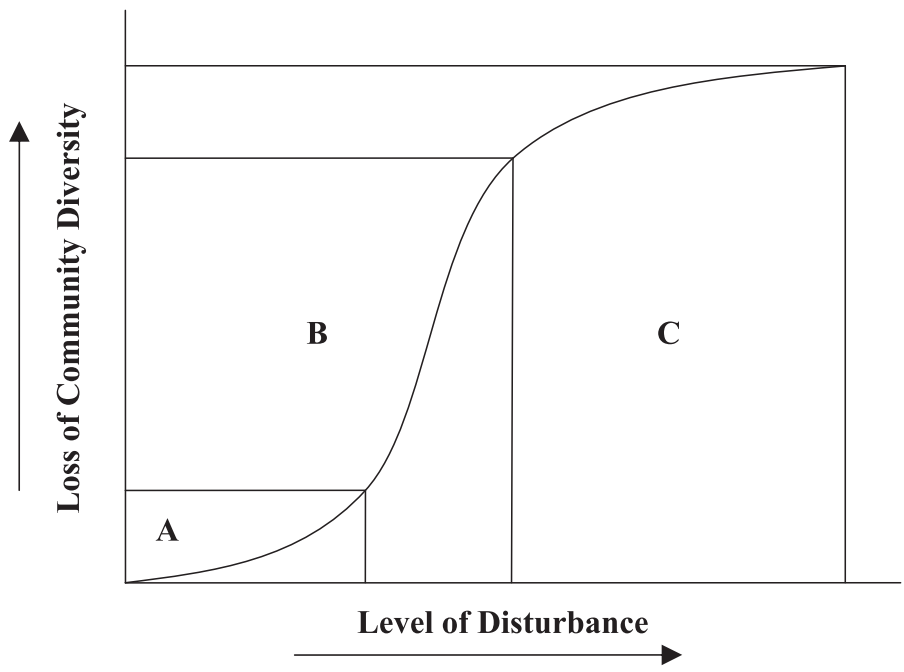

Figure 1. Conceptual model showing increased loss of community diversity with increasing disturbance. Region A: Low level of disturbance, the community is still relatively resilient/tolerant and likely to display a few early signs of change without significant alterations to community diversity. In this region of the curve, measures of functional traits may work best. Region B: Smaller levels of added disturbance result in larger changes to diversity because the influence has passed the community's tolerance/ resilience thresholds. In this region, biomonitoring indices and production measures are generally more useful because the effects from disturbance are propagated throughout the community. Region C: High level of disturbance, biomonitoring indices and production measures are less likely to be useful. In this region, the community is strongly disrupted as is physical habitat; disturbance may be better assessed by measuring the physical environment.

2001; Magurran 2004), such that more closely related species (i.e., lower diversity) characterize disturbed assemblages, while species spread across a wider array of taxonomic levels (i.e., higher diversity) reflect assemblages experiencing less disturbance (Warwick and Clarke 1995).

Groupings of plant species based on functional traits in a community compliment measures of phylogenetic diversity when assessing change because they reflect functional categories that influence the performance of a species group in its environment (e.g., Barkman 1988; Bullock et al. 2001; Lavorel and Garnier 2002). Functional diversity refers to the variety of functional traits (e.g., growth habit) and their trait states (e.g., grass, forb/herb) that describe an assemblage of organisms (e.g., Mayfield et al. 2005; Fontaine et al. 2006) and is better linked to sustained ecosystem performance than is species richness (e.g., Tilman et al. 1997; Diaz and Cabido 2001; Hooper et al. 2005; Diaz et al. 2007). Because most functional traits are conserved within major phylogenetic lineages, less disturbed communities are composed of many lineages having more trait states (i.e., higher diversity) than more disturbed communities having fewer major lineages (i.e., lower diversity) (Warwick and Clark 1995; Prinzing et al. 2008). In terms of life-cycle duration (e.g., annual, perennial), plants with shorter versus longer life cycles may experience less grazing pressure (e.g., Feeny 1976). Alternatively, plants intensively grazed throughout their growing season can be at a competitive disadvantage with plants that are dormant or quiescent during this period. Both grazing scenarios lead to more species having 
shorter life-cycle durations (e.g., Archer and Smeins 1996; Briske 1996; Lavorel et al. 1997; Diaz et al. 2007).

Given that environmental impact is negatively related with diversity (e.g., Warwick and Clarke 1995, 1998; Campbell et al. 2010), we evaluated the effect of stocking rate manipulation (used to promote pasture sustainability) on plant phylogenetic and functional diversity in a tropical native pasture used for dairy production. Our hypothesis was that indices of phylogenetic and functional diversity would decline with increased stocking rate.

\section{METHODS}

\section{Site Description}

The study was carried out at the Centro de Enseñanza, Investigación y Extensión en Ganadería Tropical (CEIEGT), Facultad de Medicina Veterinaria y Zootecnia (FMVZ), Universidad Nacional Autónoma de México (UNAM), located in the municipality of Tlapacoyan, in the state of Veracruz, Mexico (lat $20^{\circ} 02^{\prime} \mathrm{N}$, long $97^{\circ} 06^{\prime} \mathrm{W} ; 112 \mathrm{~m}$ a.s.l.). The climate classification is $\operatorname{Af}(\mathrm{m}) \mathrm{w}^{\prime \prime}(\mathrm{e})$, tropical hot and humid with rains occurring throughout the year (with most deposition occurring from June through September/October), and the average annual temperature and precipitation are $23.5^{\circ} \mathrm{C} \pm 0.5^{\circ} \mathrm{C}$ and $1991 \pm 392 \mathrm{~mm}$, respectively (García 1981). The soil in the region is characterized as acid Ultisol $(\mathrm{pH} 4.5-5.2)$, with $\mathrm{K}$ (8.5 $\mathrm{ppm})$, low nitrogen $(0.032 \%)$ and phosphorous $(2.32 \mathrm{ppm})$ and is shallow in depth $(8-30 \mathrm{~cm})$ (Toledo 1986). The arable layer is somewhat shallow $(\leq 25 \mathrm{~cm})$ and limited by a hard bottom layer (tepetate) which contains acid silicates and results in limited root penetration and impaired drainage.

\section{Animals and Experimental Design}

Holstein $\times$ Brahman (also called Zebu, or Cebú; Bos taurus L.) multiparous F1 cows with an average weight of $489.9 \pm 67.5$ $\mathrm{kg}$ were used for the study, and stocking rates of 2,3 , and 4 cows $\cdot \mathrm{ha}^{-1}$ were applied and were achieved by placing 10 cows per treatment in 5-, 3.3-, and 2.5-ha paddocks, with each treatment having 10 replicates (Jarillo-Rodríguez 2009; JarilloRodríguez et al. 2011); disease control measures for the cows were applied as needed. The paddocks were established in February 2002, and a rotational grazing plan was applied with $3 \mathrm{~d}$ of occupation and $27 \mathrm{~d}$ of rest per paddock throughout each year over the course of the study. Control paddocks were not established because such areas are not normally present; ranchers put all pastureland to use for economic and subsistence needs. Thus, our objective was to evaluate the effects of different stocking rates used for pasture management; an absence of cows in such systems is not a useful management method for ranchers and was, therefore, not available.

\section{Data Collection}

Quadrat sampling for plant community composition was performed from August to September 2007. Within each of two replicate paddocks chosen randomly from each stocking rate treatment, two linear transects (oriented along the longest pasture axis) consisting of $1000.25 \mathrm{~m}^{2}$ rectangular quadrats (equidistantly spaced to cover each transect length) were randomly laid out (but not closer than $1.5 \mathrm{~m}$ from the fence line), yielding a total of 1200 quadrats distributed over all six paddocks. Data from both transects in each replicate paddock were combined for analysis. Given that plant subspecies determination is highly impractical in the field, species was used as the ultimate level of taxonomic identification. Within each quadrat, the presence of all plant species was recorded (observed species richness). Plant taxonomic nomenclature and authority were obtained from the United States Department of Agriculture, Natural Resources Conservation Service (USDANRCS 2011), the Integrated Taxonomic Information System (ITIS 2011), the International Plant Names Index (IPNI 2011), and associated official URL links (i.e., federal, scientific society, etc.), as was information on growth habit (grass, forb/herb, subshrub, shrub, tree, and intergrades such as subshrub-shrub that reflect a species' flexibility in growth form), phylogenetic group (grass, nongrass), and life-cycle duration (annual, perennial, and annual-perennial; the latter refers to species whose life-cycle duration is flexible).

\section{Data Analysis}

Sampling effort was assessed using sample-based rarefaction curves (Gotelli and Colwell 2001) and their 95\% confidence intervals, which were calculated for each paddock (transects combined) using EstimateS, version 8.0.0 (Colwell 2007), with each curve based on 50 randomized iterations. Recorded species were organized into hierarchical taxonomic classifications (i.e., taxonomic relatedness) consisting of species, genus, family, order, and class, with all species united through the division Magnoliophyta (Table S1; available online at http://dx. doi.org/10.2111/REM-D-11-00110.s1). Phylogenetic diversity was estimated per paddock using average taxonomic distinctness (ATD; PRIMER v5, PRIMER-E Ltd., Plymouth, UK; Clarke and Gorley 2002). The index uses presence/absence data to integrate observed species richness and taxonomic relatedness to yield an average path length connecting species pairs chosen at random from all species collected (Clarke and Warwick 1998). Examinations of statistical properties, index performance, and the differential weighting of step lengths between hierarchical taxonomic levels have shown average taxonomic distinctness is a robust index for the assessment of effects from environmental impact (Clarke and Warwick 1998, 1999; Warwick and Clarke 1998; Schweiger et al. 2008), even with variations in sampling effort (Price et al. 1999), and the data do not suffer from the variance-related problems associated with abundance-based sampling (e.g., Gotelli and Rohde 2002). Thus, sampling effort can be applied expediently to provide a rapid survey assessment of community structure and composition.

Functional diversity was calculated using the Shannon Index (e.g., Girão et al. 2007) on the proportion of species among trait states within the functional traits of growth habit and lifecycle duration. Spearman rank correlation coefficients (Zar 1984) were calculated between observed species richness, average taxonomic distinctness, and the functional diversity for growth habit and life-cycle duration across stocking rates to see whether stocking rate influenced the importance of species interactions in plant community assembly (e.g., Prinzing et al. 2008); significance was set at $\alpha=0.1$. Kruskal-Wallis tests 
$(\alpha=0.1)$ with two replications per treatment were conducted across stocking rates on observed species richness, average taxonomic distinctness, and functional diversity based on growth habit and life-cycle duration. Single-factor analyses of variance $(\alpha=0.1)$ were used to analyze the proportions of species in each phylogenetic group and life-cycle duration (for which both variables were arcsine square-root transformed prior to analysis) (Zar 1984). When response means differed significantly, a Tukey multiple comparison test was applied $(\alpha=0.1)$ (Zar 1984).

\section{RESULTS}

Sampling efforts provided a total of 56 plant species distributed across 37 genera, 18 families, 13 orders, and 2 classes (Table S1). Examination of the sample-based rarefaction curves revealed sampling efforts were adequate, and that sampling adequacy improved as stocking rate increased (Fig. 2). At the highest stocking rate, curves from the randomly chosen replicate paddocks for a stocking rate treatment were more similar to each other, and observed species richness in the two paddocks also was more similar.

Observed species richness, average taxonomic distinctness, and functional diversity based on growth habit and life-cycle duration did not differ significantly across stocking rates $(H=2.279, H=3.215, H=3.714, H=3.714$, respectively, $P>0.1$ in all cases; Figs. 3 and 4). Most species were perennial, and their proportion declined significantly with increased stocking rate $(F=16.36,0.05>P>0.02)$, while the proportion of annual-perennial species increased significantly with stocking rate $(F=76.88,0.01>P>0.005$; Fig. 5$)$. The proportion of annual species was least prominent and did not differ significantly across stocking rates $(F=2.4,0.5>P>0.2)$. Although the proportion of nongrass species was greater than for grasses, the values within each phylogenetic group did not differ significantly across stocking rates $(F=0.956$ and $F=0.976$, respectively; $P>0.5$ in both cases; Fig. 5). A breakout of the nongrasses by growth habit showed the majority were forb/herbs and forb/herb-subshrubs (Fig. 6).

Spearman rank correlation coefficients between the different pairs of variables revealed two highly significant positive correlations, one between the functional diversity for life-cycle duration and average taxonomic distinctness, and the other between observed species richness and functional diversity based on growth habit (Table 1).

\section{DISCUSSION}

A relatively rapid and significant increase in the proportion of annual-perennial species was observed with increased stocking rate, as was a significant decrease in the proportion of perennial species. These changes do not indicate improved sustainability of the pasture plant community. Increased grazing pressure promoted more short-lived plants or good dispersers that colonized disturbed areas produced by grazers. Longer-lived plants are more damaged by grazing and cannot exploit openings (bare zones or areas with reduced competition) (Feeny 1976; Briske 1996; Archer and Smeins 1996; Lavorel
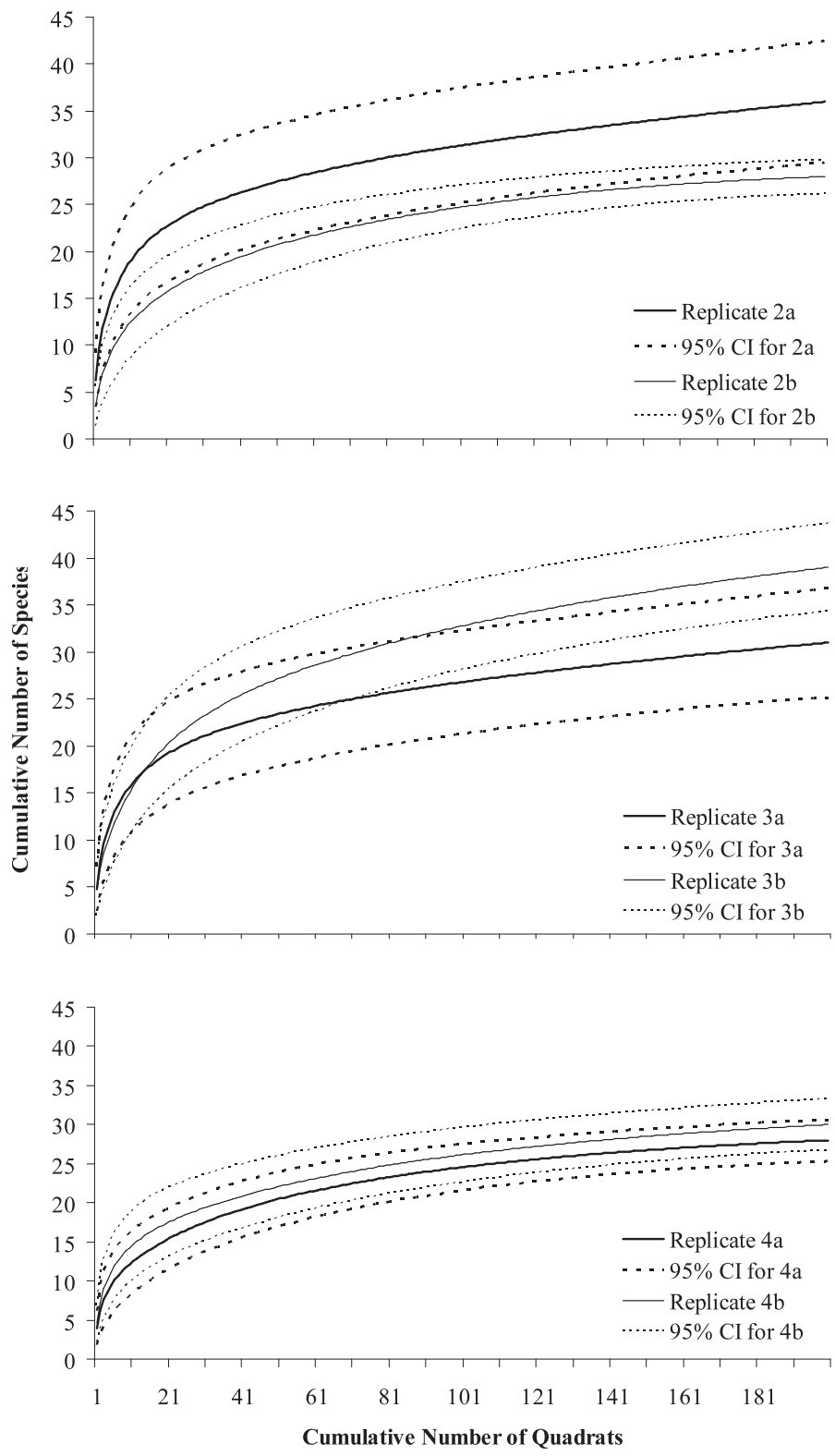

Figure 2. Sample-based rarefaction curves and their 95\% confidence intervals $(\mathrm{Cl})$ for two randomly chosen replicate paddocks in each of the three stocking rates (replicate letters, a and b, are for graphic reference).

et al. 1997; Bullock et al. 2001). Although there was no species survey prior to paddock establishment, Jarillo-Rodríguez (2009) reports that the vegetation at the beginning of the experiment was relatively homogeneous in distribution and was composed of $86.9 \%$ native grasses, $2.9 \%$ introduced grasses, $1.7 \%$ native leguminous species, and $8.5 \%$ wide- and narrow-leafed weeds, thus supporting the assertion that the results were grazing-induced.

In the principal investigation preceding this report, JarilloRodríguez (2009; see also Jarillo-Rodríguez et al. 2011) revealed no significant effects from stocking rate on standard measures of yield, nutritive quality, or pasture utilization for the dominant and abundant forage grasses Axonopus compressus (Sw.) P. Beauv. and Paspalum notatum Alain ex Flüggé in the study site (i.e., tillers $\cdot \mathrm{m}^{-2}$, leaf area, foliar growth rate, level of tiller use, tiller length and height, number of 

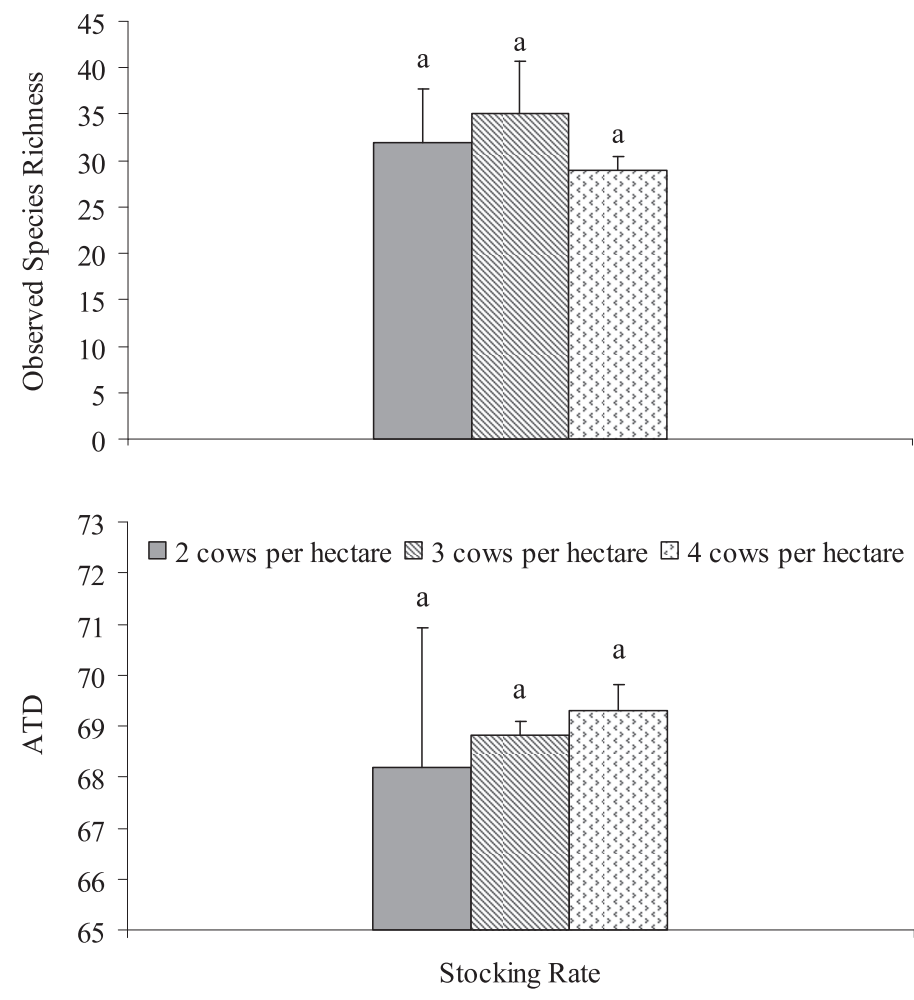

Figure 3. Observed species richness and average taxonomic distinctness (ATD) by stocking rate (SD whisker above each bar). The same letters above each bar indicate no significant difference $(\alpha=0.1)$.

leaves $\cdot$ tiller $^{-1}$, dry matter, root length, leaf and stem crude protein, neutral detergent fiber, and rumen digestion of leaf dry matter), although the amount of bare ground increased significantly with stocking rate. Further, stocking rates in Veracruz pastures are reported to range from 1.4 (Menocal et al. 1992) to 2.9 cows $\cdot \mathrm{ha}^{-1}$ (Aluja and McDowell 1984; Hernández et al. 1998; Alarcón et al. 1999) without apparent negative effects on pregnancy rates of cows, weaning weight of calves, or calf weight gain. Without considering the proportional contributions of the different plant functional trait states, these production measures might suggest that pasture sustainability management methods were working. However, contri-

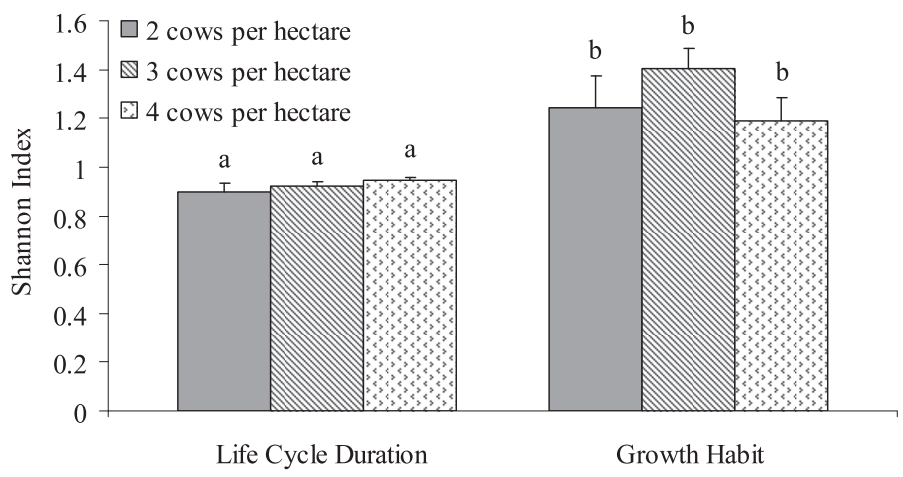

Figure 4. Functional diversity (Shannon Index) across stocking rates for life-cycle duration and growth habit. The similar letters above the bars within each functional trait indicate no significant difference $(\alpha=0.1$; SD whisker above each bar).
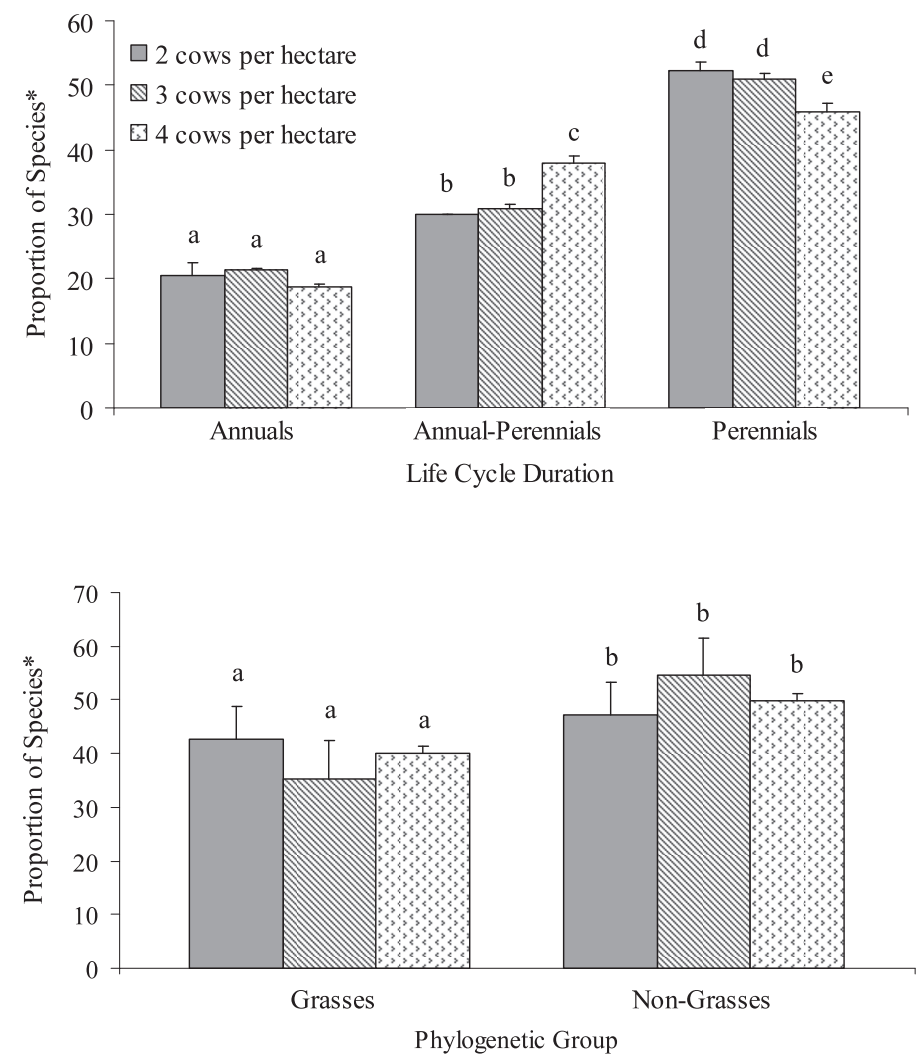

Figure 5. Proportion of species ( ${ }^{*}=$ arcsine square-root transformed) by stocking rate for life-cycle duration and phylogenetic group. Different letters above the bars indicate significant differences within each functional trait state $(\alpha=0.1 ; \mathrm{SD}$ whisker above each bar).

butions from the functional trait states instead suggest that plant communities were responding, but had not yet responded sufficiently so that effects involving diversity indices and measures of forage quality were not realized. The significant and positive correlation between observed species richness and functional diversity based on growth habit (Table 1) suggests that if longer or higher grazing pressure did result in the decline

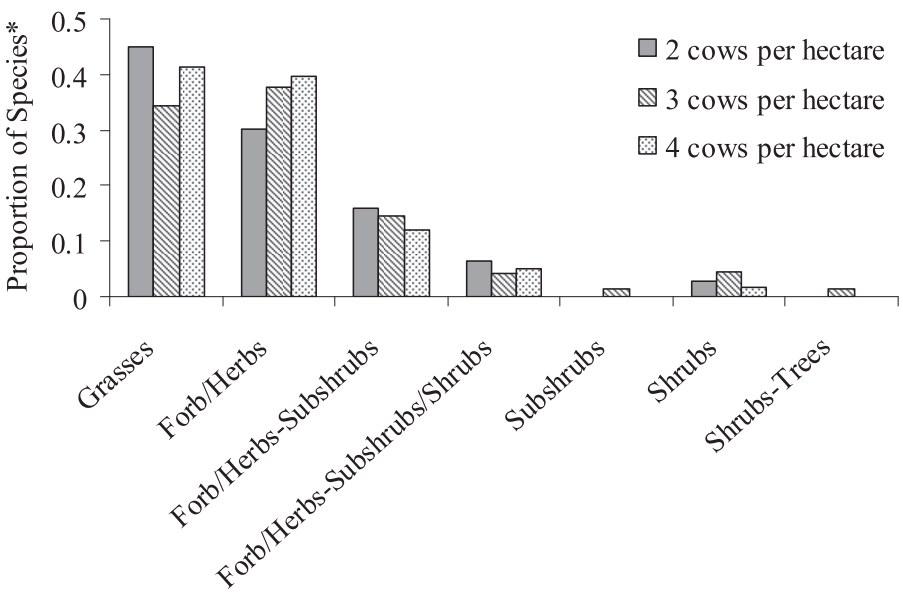

Growth Habit

Figure 6. Proportion of species in each of the different growth habits across stocking rates $\left({ }^{*}=\right.$ values are averages of the two transects per grazing treatment). 
Table 1. Spearman rank correlation coefficients among pairs of biological indices across the three stocking rates $\left(\alpha=0.1 ;{ }^{*}=\right.$ significant; $\mathrm{SR}=$ observed species richness, $\mathrm{ATD}=$ average taxonomic distinctness, $H(L C D)=$ functional diversity based on life-cycle duration, $H(G H)=$ functional diversity based on growth habit.

\begin{tabular}{lcccc}
\hline & SR & ATD & $H(L C D)$ & $H(G H)$ \\
\hline SR & 1 & & & \\
ATD & -0.5 & 1 & & \\
H(LCD) & -0.5 & $1^{*}$ & 1 & \\
H(GH) & $1^{*}$ & -0.5 & -0.5 & 1 \\
\hline
\end{tabular}

of species richness or growth habit diversity, then the other would also likely decline. As such, responses to grazing were most likely closer to the upper end of region A in Figure 1.

Positive correlations between indices of phylogenetic diversity and functional diversity may reflect a random community assembly process that draws from the surrounding species pool (Prinzing et al. 2008; see also Foster et al. 2004; Dickson and Foster 2008). This type of assembly process very often leads to the establishment of opportunistic species in the community (e.g., Fleischner 1994; DiTomaso 2000; Milchunas 2006; Vavra et al. 2007). Although the degree of change depends on the ecosystem, plant community, environmental conditions, and intensity and timing of grazing, changes have generally been more evident in ecosystems where grazing ungulates have been historically scarce or absent (Milchunas 2006) (e.g., the Mexican tropics). In contrast, in undisturbed communities with a more stable composition, interspecies interactions dominate the filtering of immigrant species. The strong positive correlation between phylogenetic and functional diversity and lack of significant change in either of these diversity indices across the grazing treatments suggests that community assembly is random in all the imposed levels of grazing pressure. In this case the colonization success of immigrant species is based on their rapidity of establishment and growth. Habitats open to colonization, such as those in the higher stocking rates and bare ground in this study, present opportunities and challenges to land managers. Open habitats may be good for restoration by seed or manual plantings, but such communities also are more unstable and susceptible to the entrance and establishment of less competitive, opportunistic, and toxic species. Indeed, both Heliotropium indicum L. (India Heliotrope) and Solanum americanum Mill. (American Black Nightshade), species known to be toxic to livestock and to establish better in disturbed sites, were observed in the two higher stocking rates.

Reductions in the proportion of perennial species and increases in the proportion of annual-perennial species prior to and during the study may also occur because of climate change. Global warming is altering precipitation and temperature patterns throughout many regions of the world. In the state of Veracruz, between 1969 and 1998, rainfall declined by $40 \mathrm{~mm}$ per year, and temperature decreased by $0.02^{\circ} \mathrm{C}$ per year (Gay et al. 2006). Annual precipitation in the state is predicted to decline further between $5 \%$ and $20 \%$ (IPCC 2007), and one form of adaptation by plant communities to reduced precipitation is to increase the number of species with shorter or more flexible life-cycle durations. Such flexibility allows new populations to explore novel habitats having variable quantity and quality of resources, and to improve the survivability of others in existing habitats exposed to variable or prolonged change in resource availability (Archer and Smeins 1996; Barbour et al. 1998). Although climate change may have already shifted these plant communities to have shorter or more flexible life cycles, similar shifts caused by grazing pressure were still detected. The fact that these two stresses are expected to have similar effects on the plant communities suggests greater danger of increased grazing pressure in the future than seen in the results of this study.

The greater similarity in the rarefaction curves and generally reduced $95 \%$ confidence intervals for individual curves at the highest stocking rate suggest greater uniformity of species' spatial distributions within and between replicate paddocks. Reduced grazer selectivity and therefore more uniform impacts on all plants as stocking rate increased may be the cause of this similarity. Regardless of the cause, the patterns in rarefaction curves among the stocking rate treatments imply that these curves could be useful for detecting early community responses (i.e., region A in Fig. 1).

In summary, plant responses occurring in region A of Figure 1 were better assessed using direct measures of functional traits or sample-based rarefaction curves than by using measures of animal and pasture production or diversity indices that are more suited to detecting stronger effects propagated throughout the community. However, correlations involving said indices did provide supporting complementary information to further suggest that plant community composition was likely closer to the upper end of region A in Figure 1. Thus, future research and management efforts should use measurement methods with varying sensitivities to facilitate the detection of grazing impacts so that effects are not overlooked. Reducing stocking rates may ease pressures on plant communities but may be difficult considering the poverty faced by most ranchers in the region and their resultant need to improve subsistence conditions. Progress toward pasture sustainability will require that lasting economical, educational, and ecological bridges be built with ranchers to improve pasture management practices. Implicit in this effort is that political and socioeconomic conditions promote access, practicality, and adaptivity in investigations and tangible economic returns from the application of solutions.

\section{IMPLICATIONS}

Increased stocking rates often implemented to increase animal production by improving forage value may have counterproductive effects on pasture sustainability. Such increases were associated with a decline in the proportion of perennial species, an increased presence of undesired species, and possibly decreased spatial variability among and within paddocks. Changes such as these in a pasture plant community provide an early warning to ranchers and land managers that further grazing pressure may have adverse effects on pasture sustainability; monitoring for such warning signs is prudent. The choice of measures to use for pasture monitoring should span detection sensitivities in order to provide evidence of changes in the pasture plant community before they are translated into costly or potentially irreversible shifts in forage quantity and 
quality. Compared to abundance-based assessments for monitoring plant diversity, methods employing the use of species presence-absence in this and other studies are more easily and rapidly applied in the field and provide increased costeffectiveness for sampling effort. This rapid assessment approach not only lends itself well to providing academic research and training experiences, but also can more effectively promote the integration of local ranchers and land managers (e.g., in extension, outreach, and citizen science) in field efforts, thus helping to build bridges for the improvement of pasture and economic sustainability.

\section{ACKNOWLEDGMENTS}

We thank A. Symstad and the anonymous referees for helping to improve the manuscript. We also thank Ramiro Escobar-Hernández and Horacio Díaz-Esteban for their tireless assistance in the field.

\section{LITERATURE CITED}

Ackerman, C. J., H. T. Purvis II, G. W. Horn, S. I. Paisley, R. R. Reuter, and T. N. Bodine. 2001. Performance of light vs. heavy steers grazing Plains Old World bluestem at three stocking rates. Journal of Animal Science 79:493-499.

Alarcón, R. F., G. E. Castillo, G. I. Rubio, and H. C. Galina. 1999. Efecto de dos cargas animal sobre la productividad de vacas Brahman en un sitio con clima Af(m), y suelos ultisoles. In: XXXV Reunión Nacional de Investigación Pecuaria. Mérida, Yucatán, Mexico: Instituto Nacional de Investigaciones Forestales, Agrícolas y Pecuarias. $95 \mathrm{p}$.

AlujA, S. A., AND R. McDowell. 1984. Livestock production systems in central Veracruz State, Mexico. Ithaca, NY, USA: Cornell University Press. $404 \mathrm{p}$.

Améndola, R., E. Castillo, and P. A. Martínez. 2005. Forage resource profiles. Mexico. In: Country pasture profiles (CD). Rome, Italy: FAO.

ARCHER, S. 1995. Herbivore mediation of grass-woody plant interactions. Tropical Grasslands 29:218-235.

ARCHER, S. 1996. Assessing and interpreting grass-woody plant dynamics. In: J. Hodgson and A. W. Illius [EDS.]. The ecology and management of grazing systems. Oxfordshire, UK: CAB International. p. 101-134.

ArCheR, S., ANd F. E. Smeins. 1996. Ecosystem-level processes. In: R. K. Heitschmidt and J. W. Stuth [EDS.]. Grazing management: an ecological perspective. Portland, OR, USA: Timber Press. p. 109-139.

ArgeL, P. 2006. Contribution of improved pastures to animal productivity in dual purpose systems. Archivos Latinoamericanos de Producción Animal 14:65-72.

Asner, G. P., A. J. Elmore, L. P. Olander, R. E. Martin, and A. T. Harris. 2004. Grazing systems, ecosystem responses, and global change. Annual Review of Environment and Resources 29:261-299.

Barbour, M. G., J. H. Burk, W. D. Pitts, F. S. Gilliam, and M. W. Schwartz. 1998. Terrestrial plant ecology. 3rd ed. Menlo Park, CA, USA: Benjamin Cummings. 688 p.

BARKMAN, J. J. 1988. New systems for plant growth forms and phenological plant types. In: M. J. A. Werger, P. J. M. van den Aart, H. J. During, and J. T. A. Verhoeven [EDS.]. Plant form and vegetative structure. The Hague, the Netherlands: SPB Academic Publications. p. 9-44.

BRISKE, D. D. 1996. Strategies of plant survival in grazed systems: a functional interpretation. In: J. Hodgson and A. W. Illius [EDS.]. The ecology and management of grazing systems. Oxfordshire, UK: CAB International. p. 37-67.

Briske, D. D., and R. K. Heitschmidt. 1991. An ecological perspective. In: R. K. Heitschmidt and J. W. Stuth [EDS.]. Grazing management-an ecological perspective. Portland, OR, USA: Timber Press. p. 11-26.

Bullock, J. M., J. Franklin, M. J. Stevenson, J. Silvertown, S. J. Coulson, S. J. Gregory, AND R. TOFTs. 2001. A plant trait analysis of responses to grazing in a long-term experiment. Journal of Applied Ecology 38:253-267.

Campbell, W. B., D. C. Freeman, J. M. Emlen, and S. López-Ortiz. 2010. Correlations between plant phylogenetic and functional diversity in a high altitude cold salt desert depend on sheep grazing season: implications for range recovery. Ecological Indicators 10:676-686.

Castlllo, G. E., M. B. Valles, L. 't Mannetue, and S. A. Aluja. 2005. Efecto de introducir Arachis pintoi sobre variables del suelo de pasturas de grama nativa del trópico húmedo mexicano. Técnica Pecuaria en México 43:287-295.

Clarke, K. R., and R. M. Warwick. 1998. A taxonomic distinctness index and its statistical properties. Journal of Applied Ecology 35:523-531.

Clarke, K. R., and R. M. WarWICK. 1999. The taxonomic distinctness measure of biodiversity: weighting of step lengths between hierarchical levels. Marine Ecology Progress Series 184:21-29.

Clatke, K. R., and R. M. WarWICK. 2001. A further biodiversity index applicable to species lists: variation in taxonomic distinctness. Marine Ecology Progress Series 216:265-278.

Clarke, R., and R. Gorley. 2002. PRIMeR 5 for Windows, version 5.2.9. Plymouth Marine Laboratory, UK: PRIMER-E Ltd.

CoLweLL, R. K. 2007. EstimateS: statistical estimation of species richness and shared species from samples. Version 8.0.0. Available at: http://purl.oclc.org/estimates.

Dabo, S. M., C. M. Tallaferro, S. W. Coleman, F. P. Horn, and P. L. Claypool. 1987. Yield and digestibility of Old World bluestem grasses as affected by cultivar, plant part, and maturity. Journal of Range Management 40:10-15.

Dabo, S. M., C. M. Tallaferro, S. W. Coleman, F. P. Horn, and P. L. Claypool. 1988. Chemical composition of Old World bluestem grasses as affected by cultivar and maturity. Journal of Range Management 41:40-48.

DIAZ, S., AND M. CABIDO. 2001. Vive la difference: plant functional diversity matters to ecosystem properties. Trends in Ecology and Evolution 16:646-655.

Diaz, S., S. Lavorel, S. Mclntyre, V. Falczuk, F. Casanoves, D. G. Milchunas, C. Skarpe, G. Rusch, M. Sternberg, I. Noy-Meir, J. Landsberg, W. Zhang, H. Clark, and B. D. CampBell. 2007. Plant trait responses to grazing-a global synthesis. Global Change Biology 13:313-341.

Dickson, T. L., AND B. L. Foster. 2008. The relative importance of the species pool, productivity and disturbance in regulating grassland plant species richness: a field experiment. Journal of Ecology 96:937-946.

DiTomaso, J. M. 2000. Invasive weeds in rangelands: species, impacts, and management. Weed Science 48:255-265.

Edwards, A. C., Y. Cook, R. Smart, and A. J. Wade. 2000. Concentrations of nitrogen and phosphorous in streams draining the mixed land-use Dee catchment, northeast Scotland. Journal of Applied Ecology 37(Suppl. 1):159-170.

Enriquez, Q. J. F. 1996. Producción estacional de gramíneas forrajeras tropicales en suelos ácidos del sur de Veracruz. In: Novena Reunión Científica-Tecnológica Forestal y Agropecuaria del Estado de Veracruz. Veracruz, Mexico: Sarh-INIFAP. p. $118-120$.

FeEnY, P. 1976. Plant apparency and chemical defense. Recent Advances in Phytochemistry 10:1-40.

Fike, J. H., C. R. Staples, L. E. Sollenberger, B. Macoon, and J. E. Moore. 2003. Pasture forages, supplementation rate, and stocking rate effects on dairy cow performance. Journal of Dairy Science 86:1268-1281.

FLeISCHNER, T. L. 1994. Ecological costs of livestock grazing in western North America. Conservation Biology 8:629-644.

Fonseca, C. R., and G. Ganade. 2001. Species functional redundancy, random extinctions, and the stability of ecosystems. Journal of Ecology 89:118-125.

Fontaine, C., I. Dajoz, J. Meriguet, and M. Loreau. 2006. Functional diversity of plantpollinator interaction webs enhances the persistence of plant communities. PLoS Biology 4:129-135.

Foster, B. L., T. L. Dickson, C. A. Murphy, I. S. Karel, and V. H. Smith. 2004. Propagule pools mediate community assembly and diversity—ecosystem regulation along a grassland productivity gradient. Journal of Ecology 92:435-449.

FrIEDEL, M. H. 1991. Range condition assessment and the concept of thresholds: a viewpoint. Journal of Range Management 44:422-426.

Garcia, E. 1981. Modificaciones al sistema de clasificación climática de Köppen. 3rd ed. Distrito Federal, Mexico: Instituto de Geographia, Universidad Nacional Autónoma de México. $252 \mathrm{p}$.

Gay, C., F. Estrada, C. Conde, H. Eakin, and L. Villers. 2006. Potential impacts of climate change on agriculture: a case study of coffee production in Veracruz, Mexico. Climatic Change 79:259-288.

GIBB, M. 2006. Grassland management with emphasis on grazing behavior. In: A. Elgersma, J. Dijkstra, and S. Tamminga [EDS.]. Fresh herbage for dairy cattle: the 
key to a sustainable food chain. Vol. 18, Wageningen UR Frontis Series. New York, NY, USA: Springer-Verlag. p. 141-157.

Girẫo, L. C., A. V. Lopes, M. Tabarelli, and E. M. Bruna. 2007. Changes in tree reproductive traits reduce functional diversity in a fragmented Atlantic forest landscape. PLOS ONE 2:e908, doi: 10.1371/journal.pone.0000908.

Gotelul, N. J., AND R. K. ColweLl. 2001. Quantifying biodiversity: procedures and pitfalls in the measurement and comparison of species richness. Ecology Letters 4:379-391.

GotelLI, N. J., AND K. RohDE. 2002. Co-occurrence of ectoparasites of marine fishes: a null model analysis. Ecology Letters 5:86-94.

Harper, K. T., F. T. Wagstaff, and W. P. Clary. 1990. Shrub mortality over a 54-year period in a shadscale desert, west-central Utah. In: E. D. McArthur, E. M. Romney, S. D. Smith, and P. T. Tueller [EDS.]. Proceedings-Symposium on cheatgrass invasion, shrub die-off, and other aspects of shrub biology and management; 5-7 April 1989; Las Vegas, NV, USA. Ogden, UT, USA: USDA Forest Service Intermountain Research Station. INT-GTR-276. p. 119-126.

Hernández, S. I., G. E. Castillo, G. I. Rubio, and H. C. Galina. 1998. Carga animal y edad al destete del becerro: su efecto sobre la productividad de vacas Brahman en un clima Af(m). In: Memorias de la XXIV Reunión Nacional de Investigación Pecuaria, Querétaro, Querétaro. Distrito Federal, Mexico: Instituto Nacional de Investigaciones Forestales, Agrícolas y Pecuarias. 70 p.

HolECHEK, J. L. 1996. Financial returns and range condition on southern New Mexico ranches. Rangelands 18:52-56.

Hooper, D. U., F. S. Chapin III, J. J. Ewel, A. Hector, P. Inchausti, S. Lavorel, J. H. Lawton, D. M. Lodge, M. Loreau, S. Naeem, B. Schmid, H. Setälä, A. J. Symstad, J. Vandermeer, and D. A. Wardle. 2005. Effects of biodiversity on ecosystem functioning: a consensus of current knowledge. Ecological Monographs 75:335.

IPCC. 2007. Summary for policymakers. In: S. D. Solomon, D. Qin, M. Manning, Z. Chen, M. Marquis, K. B. Averyt, M. Tignor, and H. C. Miller [EDs.]. Climate change 2007, the physical science basis. Contribution of Working Group I to the Fourth Assessment Report of the IPCC (Intergovernmental Panel on Climate Change) on climate change. Cambridge, UK: Cambridge University Press. $21 \mathrm{p}$.

IPNI. 2011. International Plant Names Index. Available at: http://www.ipni.org. Accessed 17 April 2011.

ITIS. 2011. Integrated Taxonomic Information System. Available at: http://www.itis. gov. Accessed 12 April 2011.

Jarillo-Rodriguez, J. 2009. Efecto de la carga animal sobre el suelo, la pastura y el comportamiento ingestivo de vacas pastoreando gramas nativas trópico húmedo de México [dissertation]. Mérida, Yucatán, Mexico: Universidad Autónoma de Yucatán. 162 p.

Jarillo-Rodriguez, J., E. Castillo-Gallegos, A. F. Flores-Garrido, B. Valles-de la Mora, L. Ramirez y Avilés, R. Escobar-Hernández, and E. Ocaña-Zavaleta. 2011. Forage yield, quality and utilization efficiency on native pastures under different stocking rates and seasons of the year in the Mexican humid tropic. Tropical and Subtropical Agroecosystems 13:417-427.

Johnson, K. H., K. A. Vogt, H. J. Clark, O. J. Schmitz, and D. J. Vogt. 1996. Biodiversity and the productivity and stability of ecosystems. Trends in Ecology and Evolution 11:372-377.

Kauffman, J. B., And D. Pyke. 2001. Range ecology, global livestock influences. In: S. Levins [ED.]. Encyclopedia of biodiversity. Volume 5. San Diego, CA, USA: Academic Press. p. 33-52.

Lavorel, S., and E. Garnier. 2002. Predicting changes in community composition and ecosystem functioning from plant traits: revisiting the Holy Grail. Functional Ecology 16:545-556.

Lavorel, S., S. Mclntyre, J. Landsberg, and T. D. A. Forbes. 1997. Plant functional classifications: from general groups to specific groups based on response to disturbance. Trends in Ecology and Evolution 12:474-478.

Laycock, W. A. 1991. Stable states and thresholds of range condition on North American rangelands: a viewpoint. Journal of Range Management 44:427-434.

Lyons, K. G., C. A. Brigham, B. H. Traut, and M. W. Schwartz. 2005. Rare species and ecosystem functioning. Conservation Biology 19:1019-1024.

Magurran, A. E. 2004. Measuring biological diversity. Princeton, NJ, USA: Princeton University Press. 260 p.
Manríuez, M. L. Y. 2010. Establecimiento, calidad del forraje y productividad de un sistema silvopastoril intensivo bajo pastoreo de bovinos y ovinos en el trópico sub-húmedo [dissertation]. Veracruz, Mexico: Colegio de Postgraduados, Campus Veracruz. $89 \mathrm{p}$.

Mayfield, M. M., M. E. Boni, G. C. Dally, and D. Ackerly. 2005. Species and functional diversity of native and human-dominated plant communities. Ecology 86:23652372.

McNaughton, S. J. 1979. Grazing as an optimization process: grass-ungulate relationships in the Serengeti. American Naturalist 113:691-703.

Menocal, E., S. A. Aluja, F. J. L. Dávalos, and M. A. Álvarez. 1992. Diagnostico y estrategias de desarrollo de la producción bovina lechera en la región VeracruzCentro. Vol. 1. Mexico City, Mexico: IMTA-UNAM. 110 p.

MulchunAS, D. G. 2006. Responses of plant communities to grazing in the southwestern United Status. Fort Collins, CO, USA: USDA Forest Service. RMRS-GTR-169. 126 p.

Price, A. R. G., M. J. Keeling, and C. J. O'Callaghan. 1999. Ocean-scale patterns of "biodiversity" of Atlantic asteroids determined from taxonomic distinctness and other measures. Biological Journal of the Linnaean Society 66:187-203.

Prinzing, A., R. Reilfers, W. G. Braakhekke, S. M. Hennekens, O. Tackenberg, A. A. Ozinga, J. H. J. Schaminée, and J. M. van Groenendael. 2008. Less lineages-more trait variation: phylogenetically clustered plant communities are functionally more diverse. Ecology Letters 11:809-819.

Provenza, F. D., J. J. Villalba, J. Haskell, J. W. MacAdam, T. C. Griggs, and R. D. WIEDMEIER. 2007. The value to herbivores of plant physical and chemical diversity in time and space. Crop Science 47:382-398.

Provenza, F. D., J. J. Villalba, R. W. Wiedmeier, T. Lyman, J. Owens, L. Lisonbee, A. Clemensen, K. D. Welch, D. R. Gardner, and S. T. Lee. 2009. Value of plant diversity for diet mixing and sequencing in herbivores. Rangelands 31(1):45-49.

Schwelger, 0., S. Klotz, W. DuRka, and I. KüHn. 2008. A comparative test of phylogenetic diversity indices. Oecologia 157:485-495.

Shachak, M., B. Boeken, E. Groner, R. Kadmon, Y. Lubin, E. Meron, G. Ne'eman, A. Perevolotsky, Y. Shkedy, and E. D. Ungar. 2008. Woody species as landscape modulators and their effect on biodiversity patterns. BioScience 58:209-221.

Smith, R. S., R. S. Shiel, D. Millward, and P. Corkhill. 2000. The interactive effects of management on the productivity and plant community structure of an upland meadow: an 8-year field trial. Journal of Applied Ecology 37:1029-1043.

StafFord SMitH, M. 1996. Management of rangelands: paradigms at their limits. In: J. Hodgson and A. W. Illius [EDS.]. The ecology and management of grazing systems. Oxfordshire, UK: CAB International. p. 325-357.

Tilman, D., J. Knops, D. Wedin, P. Reich, M. Ritchie, and E. Siemann. 1997. The influence of functional diversity and composition on ecosystem properties. Science 277:1300-1302.

ToleDo, J. M. 1986. Plan de investigación en leguminosas tropicales para el CIEEGT. Informe de consultoría, Documento interno. Martínez de la Torre, Veracruz, Mexico: Centro de Investigación, Enseñanza y Extensión en Ganadería Tropical, Universidad Nacional Autónoma de México. 46 p.

UngaR, E. D., AND I. Noy-MeIR. 1988. Herbage intake in relation to availability and sward structure: grazing processes and optimal foraging. Journal of Applied Ecology 25:1045-1062.

USDA-NRCS. 2011. The PLANTS database. Available at: https://plants.usda.gov. Accessed 4 April 2011.

Vavra, M., C. G. PARKS, And M. J. Wisdom. 2007. Biodiversity, exotic plant species, and herbivory: the good, the bad, and the ungulate. Forest Ecology and Management 246:66-72.

Villa-Herrera, A., M. E. Nava-Tablada, S. López-Ortiz, S. Vargas-López, E. OrtegaJimenez, And F. Gallardo-López. 2009. Use of Guacimo (Guazuma ulmifolia Lam.) as a forage source for extensive livestock production in a tropical area of Mexico. Tropical and Subtropical Agroecosystems 10:253-261.

Warwick, R. M., and K. R. Clarke. 1995. New "biodiversity" measures reveal a decrease in taxonomic distinctness with increasing stress. Marine Ecology Progress Series 129:301-305.

Warwick, R. M., and K. R. Clarke. 1998. Taxonomic distinctness and environmental assessment. Journal of Applied Ecology 35:532-543.

ZAR, J. H. 1984. Biostatistical analysis. 2nd ed. Englewood Cliffs, NJ, USA: PrenticeHall. $718 p$. 